\title{
Abundance, distribution and conservation threats of African wild dog (Lycaon pictus) in the Loliondo Game Controlled Area, Tanzania
}

\author{
EMMANUEL MASENGA, SHOMBE N. HASSAN", KASHAIGILI JAPHET \\ Department of Wildlife Management, College of Forestry, Wildlife and Tourism, Sokoine University of Agriculture. Morongo, Tanzania. P.O. Box: 3073 \\ Tel.: +255-23-2601376, "email: hassanshombe@yahoo.com
}

Manuscript received: 13 March 2019. Revision accepted: 17 June 2019.

\begin{abstract}
Masenga E, Hasan SN, Japhet K. 2018. Abundance, distribution, and conservation threats of African wild dog (Lycaon pictus) in the Loliondo Game Controlled Area, Tanzania. Asian J For 2: 31-41. African wild dog (Lycaon pictus) is of high conservation importance due to its few populations remaining while it is threatened with various factors. Assessment of abundance, distribution, and conservation threats to African wild dogs was conducted in Loliondo Game Controlled Area (LGCA), northern Tanzania. Specifically, the study focused on determining population size and structure, spatial distribution, attitudes of local people towards wild dogs and wild dog conservation and threats impacting the species. Semi-structured interviews, diurnal random searches, internal and external examinations of wild dogs carcasses examined, and night transect surveys were employed. Eight packs with a total of 132 recognized individuals at an average pack size of $16.50 \pm$ SD 7.50 individuals were recorded. Pack sizes of 3 individuals were reported to be sighted mostly and of all respondents $(n=210)$, only $26 \%$ were able to recognize wild dog sexes. The density of both known and unknown wild dogs was 0.19 animals $/ \mathrm{km}^{2}$, higher compared to other carnivores. In terms of distribution, most of the packs were concentrated in the northern part as compared to the central and southern parts of LGCA. The species was observed to occur most in woodland types of vegetation. Interestingly, $55.30 \%$ of respondents showed a positive attitude towards wild dogs and wild dog conservation despite that $52.90 \%$ of respondents dismissed lack of any conservation action or strategy in place towards conserving the species. However, poisoning and Canine Distemper Virus were identified as the main threats. Therefore, conserving African wild dogs in LGCA requires multi-approach conservation efforts (i.e. awareness rising to community, fitting radio telemetry to the dogs, and threats management interventions) due to nature of the species.
\end{abstract}

Keywords: Distribution, conservation, Loliondo, Lycaon pictus, Tanzania

\section{INTRODUCTION}

The African wild dog (Lycaon pictus) is one of the world's most endangered large carnivores (Woodroffe et al. 2004) and yet of high value to Africa's tourism industry (Lindsey et al. 2007). The reason for its current conservation category is the small population size and ongoing decline (Woodroffe et al. 2004). In the wild, fewer than 8000 individuals remain, spread across a small number of fragmented populations (IUCN/SSC 2008).

Although the highest densities of the wild dog have been recorded in wooded savannah (Creel and Creel 2002), their populations have also been recorded in habitats as diverse as short grasslands, montane forests (Dutson and Sillero-Zubiri 2005) and mangroves (McNutt et al. 2008). Historically, the species was once distributed across the African continent, absent only from the jungles and deserts (Woodroffe 2004; McNutt et al. 2008). Today, African wild dogs remain uncommon even in essentially less disturbed wilderness, apparently due to negative interactions with larger carnivores and livestock predation (Creel and Creel 1996; Mills and Gorman 1997; Woodroffe et al. 2005).

All large carnivores need large areas to survive hence African wild dogs need larger areas than almost any other terrestrial carnivore species anywhere in the world (Woodroffe et al. 2005). However, dramatic range reductions resulting from extensive habitat loss and persecution mean that they now occupy just $7 \%$ of their historical range (Woodroffe 1997; IUCN/SSC 2008). Frequently reported major causes for the decline of the species to include habitat loss, persecution, competition with other carnivores, low prey availability, and contagious diseases particularly rabies and canine distemper (Alexander and Appel 1994; Woodroffe and Ginsberg 1998; van de Bildt et al. 2002). Other causes are snares and roadkill (Woodroffe et al. 2004), and low genetic variation within a population over time (Oliver 2009).

The aims of the study were (i) To determine population size and structure of African wild dogs; (ii) To assess the spatial distribution of African wild dogs; (iii) To determine and assess threats impacting African wild dogs; (iv) To determine attitudes of local people towards the wild dogs and wild dog conservation.

\section{MATERIALS AND METHODS}

\section{Study area \\ Location}

The study was conducted in Loliondo Game Controlled Area (LGCA), which falls within the Serengeti Ecosystem in northern Tanzania. In addition, African wild dogs in adjacent protected areas, i.e. NCAA and Maasai Mara, were studied. Loliondo Game Controlled Area (Fig. 2) lies 
within the Maasai ancestral lands between latitudes $2^{\circ} 5^{\prime}$ $00^{\prime \prime}$ and $2^{\circ} 2^{\prime} 60^{\prime \prime} \mathrm{S}$; and longitude $35^{\circ} 61^{\prime} 67^{\prime \prime}$ and $35^{\circ} 37^{\prime}$ 00" E. It encompasses an estimated area of $4000 \mathrm{~km}^{2}$, roughly one-third of the area of Serengeti National Park. There are no physical barriers separating the LGCA from the bordering protected areas.

\section{Climate and vegetation}

Generally, the climate is warm and dry, coolest from June to October, with a mean annual temperature of $20.8^{\circ} \mathrm{C}$, which is often less than the diurnal variation (UNEP 2008). The average annual rainfall varies between $400 \mathrm{~mm}$ and $600 \mathrm{~mm}$ (Homewood et al. 2001). However, LGCA exhibits a bi-modal rainfall pattern with peaks occurring in December and April and a total of 400$1200 \mathrm{~mm}$ per annum (Norton-Griffiths et al. 1975).

The vegetation in LGCA varies from open woodland to short grass plains. The northern part is primarily of open woodlands on rolling hills, interspersed with rocky outcrops. It consists of a mosaic of Acacia drepanolobium in black cotton soils, high altitude forests of Pencil cedar, long grass plains dominated by Acacia gerardii, Rhus natalensis, Euclea divinorum, and Acacia hockii tree species (Homewood et al. 2001). The forests are mostly situated on the hilltops or along watercourses in valleys. The mountain forests are classified as closed evergreen forests, which contain major tree species such as Fagaropsis anglolensis (Olmoljoi), Olea welwitschii (Ololiondo) and Juniperus procera (Oltarakwa). Acacia species are dominant in open scattered valley forests (Ojalammi 2006). Short grass plains with a high net primary productivity during rains (Sinclair et al. 2002) are present to the South converging into Acacia/Commiphora woodland. The short grass plains are important breeding grounds of Wildebeest (Connochaetes taurinus). In the central part, and in and around the Sonjo area, there are mountains with steep slopes and densely vegetated gullies. In the south, the Gol Mountains give way to the short grass plains (Sinclair et al. 2002).

\section{Wildlife}

Loliondo is an important part of the semi-annual migratory route of millions of wildebeests and other ungulates northward into the Maasai Mara Game Reserve and Amboseli National Park in Kenya between April and June, and returning southward between December to January every year. The survival of the NgorongoroSerengeti-Maasai Mara ecosystem and the wildlife it supports is highly linked to the existence and health of Loliondo (Homewood et al. 2001). The Gol Mountains and Sanjan Gorge are important nesting refuges for Rüpell's Griffon Vulture (Gyps rueppellii) and White Backed Vulture (Gyps africanus) both of which are near-threatened (Ojalamini 2006). Carnivores such as African wild dog (Lycaon pictus) (endangered) and cheetah (Acinonyx jubatus) (threatened) are present (Sinclair et al. 2002).

\section{Attributes of the human communities}

The human population density in the eastern part of the ecosystem (LGCA) decreases from north to south with the highest density is found close to Kenyan border and around Wasso and Loliondo towns in the north, and the lowest density is in the Gol Mountains area in the south, where there are mainly seasonal settlements of nomadic Maasai (Masenga and Mentzel 2005). Currently, the human population of Loliondo District is estimated at 176,607, of which 85,684 are males and 90,923 are females. The estimate is computed using $4.5 \%$ annual growth rate (NDC 2009). Human activities such as settlement, cultivation (including mechanized commercial farming), pastoralism, tourism, and licensed hunting are permitted (Homewood et al. 2001) in the area. The economic activities of local communities include agro-pastoralism, with more of them engaged in livestock keeping (about 80\%) and small-scale agriculture (13\%) production system (NDC 2009).

Overall, there were 16 study villages in the studied areas even though the semi-structured interviews were limited to only 6 villages. The age structure (in years) of respondents consisted of four categories: 31-40 (5\%), 41$50(26 \%), 51-60(38 \%)$ and $>61(23 \%)$. However, $8 \%$ of individuals had no knowledge at all of their ages. Majority of respondents $(126 ; 60.80 \%)$ had primary school education whereas 50 respondents $(23 \%)$ had no formal education. Other education categories were standard twelve year with 26 respondents $(12.40 \%)$, diploma 7 respondents $(3.30 \%)$, and University education 1 respondent $(0.50)$. Numbers and corresponding percentages for the sex of respondents interviewed are summarized in Table 1.

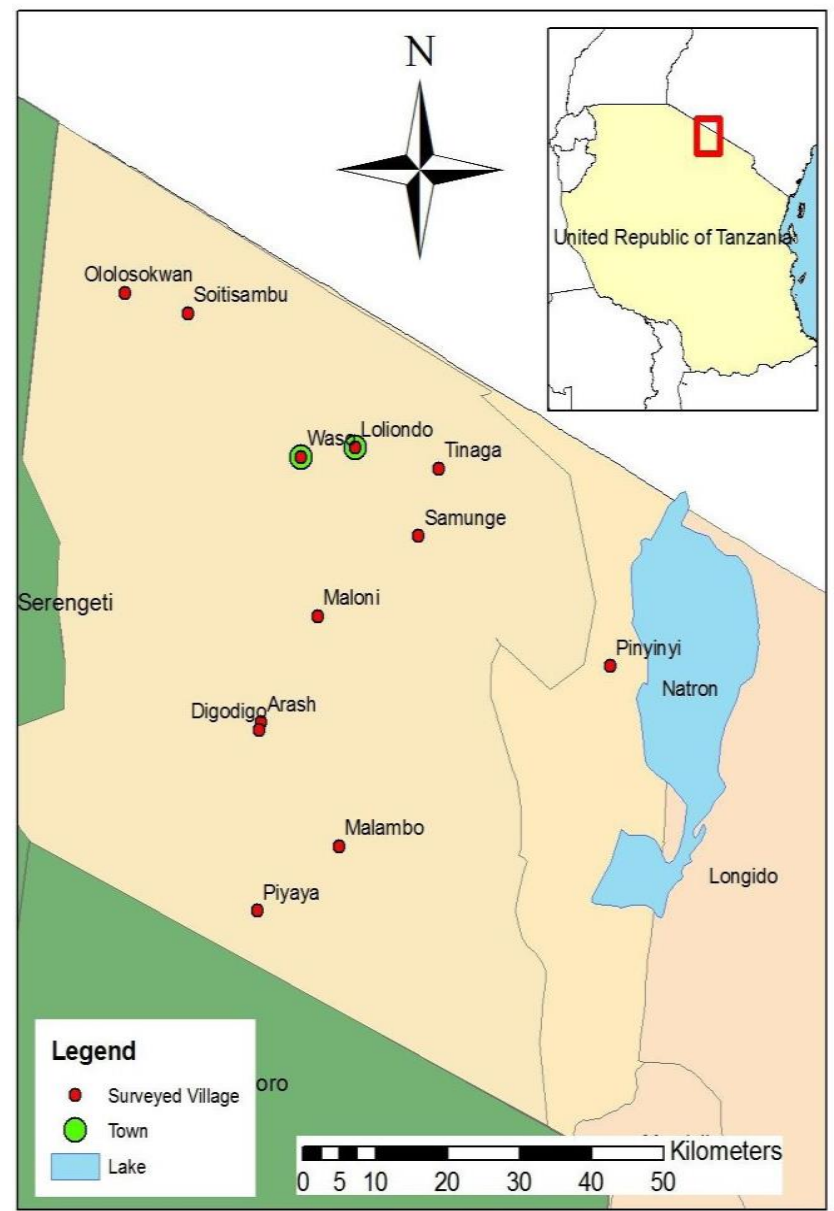

Figure 2. Map of Loliondo GCA showing surveyed villages 2009 
Table 1. The distribution of the respondents by village in respect of sex

\begin{tabular}{lcccccc}
\hline \multirow{2}{*}{ Respondents } & & \multicolumn{2}{c}{ Villages } & Digodigo & Samunge \\
\hline Male & Ololosokwan & Soitsambu & Piyaya & Malambo & Digodion & $27(77 \%)$ \\
Female & $30(86 \%)$ & $34(97 \%)$ & $33(94 \%)$ & $26(74 \%)$ & $17(49 \%)$ & $8(23 \%)$ \\
Total & $5(14 \%)$ & $1(3 \%)$ & $2(6 \%)$ & $9(26 \%)$ & $18(51 \%)$ & 35 \\
\hline
\end{tabular}

\section{Data collections}

Primary data were collected based on three methods namely, diurnal random search of wild dogs, systematic night field surveys, internal and external examination of wild dogs carcasses, and semi-structured interviews. This approach was necessary due to rarity of the subject animal. Secondary data were obtained from unpublished reports and journal publications at Tanzania Wildlife Research Institute (TAWIRI) and at Sokoine National Agricultural Library (SNAL).

\section{Population size, structure, and distribution of wild dogs}

Diurnal random searches of wild dogs were conducted in areas historically known to have wild dogs. The searches were made by a team comprising of the researcher and enumerators (persons trained to locate wild dogs and make records). Pack sizes, age, and sex of sighted individuals and positions were recorded for each pack encountered. Positions were recorded with the aid of a handheld Global Positioning System tool (GPS-Garmin 12) for mapping distribution. Photographs were taken using a highresolution camera (8.0 megapixel) for subsequent individual/pack identification (IDs). A binocular was used to aid determination of pack sizes and individual/pack identification where possible. Also, habitat/vegetation types were identified, and den sites and number of pups together with any incidence of wild dog attack by other carnivores were recorded.

Systematic night field surveys of carnivores along four major roads (Piyaya plain-Piyaya Suyan campsite, Maloni village centre-Samunge Hahara sub-village, Malambo Lake Natron junction-Malambo village center and Gol road junction-Nasera rock) were employed. A total of $20 \mathrm{~km}$ along each road were surveyed. In this case, each road was treated as a transect. Transects were driven at a fixed speed of $20 \mathrm{~km} / \mathrm{hr}$ (Buckland et al. 2001), with two observers and one recorder seated at the back of a Land Rover station wagon. Each observer scanned one side of the road using a handheld spotlight. Name of carnivore species, group size, side of the road (right/left), the perpendicular sighting distance, position, time of sighting, and kilometer driven was recorded every time a carnivore species was seen.

\section{Peoples attitudes towards wild dogs and threats of wild dog conservation}

Attitudes. The purposive sampling technique was used to select six villages from the government register book in which to conduct interviews. The villages selected were Ololosokwan, Soitsambu, Piyaya, Malambo, Samunge, and Digodigo. The sampling unit, in this case, was a household.
According to der Gier (2004), sample size should be at least 30 to 50 to ensure adequate representation of the population. Therefore in this study, the sample size was 35 households per village. Simple random sampling design was used to obtain the households sampled. The design is preferred over other designs because it gives each unit in the population an equal probability of being selected, and all choices are independent of one another. Under this method, the whole population is taken as a single composite unit (Sancheti and Kapoor 2007). Subsequently, semi-structured interviews with household representatives from villages surrounding the study area were employed. Respondents included three Ilgwanak (Head of Maasai traditional norms of different age groups) and five key informants per village (i.e. village executive officer, village chairman, village environment committee officer, village game scout officer, and teacher). The information regarding merits and demerits of wild dogs, conservation threats of wild dogs, activities/sources of threats, and mitigation of threats on wild dog conservation were focused. The survey had four main sections: (i) Respondent characteristics, (ii) African wild dog general information, (iii) Main threats facing wild dog populations, and (iv) Attitudes of local communities towards conservation of wild dogs.

Threats. Internal and external examinations of wild dog carcasses encountered during the survey were conducted and recorded. Some fresh carcasses were found near water sources suggesting mortality occurred few days ago before they were discovered. These carcasses looked very dehydrated, brownish, and swelling under the tails in most cases with open recta (evidence of severe bloody diarrhea). Eleven out of 23 fresh carcasses collected were examined for the cause of death.

The lungs appeared reddish-brown to black with extensive hemorrhages with consolidation in parts of the lobes with or without emphysema. The diaphragmatic muscles were congested with reddish to brown discoloration. The livers were slightly enlarged with thick margins and dark in color with portions of cooked-like appearance. The spleen was enlarged with thick margins, and evenly distributed dark and brown patches on both sides. In some cases, kidneys were only congested; however, in others, they appeared enlarged with evidence of hemorrhages on cut surfaces. The stomach was empty in most of the carcasses while only few had scanty brownish watery contents. The thoracic cavity was filled with reddish to brown colored fluid (sanguineous fluid or fibrin) and there was congestion in the inner surfaces of the chest cavity (pleura). 
Visceral organs including lungs, heart, intestines, liver, spleen, kidneys, lymph nodes, salivary glands, and brain were collected and examined. These samples were used for screening of Canine Distemper Virus. Tissue samples in duplicates were preserved in glycerol saline, $10 \%$ buffered formalin, ethanol, methanol, and RNA later, and thereafter the samples were frozen. Only tissues preserved in glycerol saline were used for bacterial culture. In addition, $10 \%$ buffered formalin, ethanol and methanol were used to fix tissues for histopathological examination whereas tissues in RNA were used for virus isolation and sequencing.

\section{Data analysis}

Population size, structure, and distribution

The data from the systematic night field surveys of carnivores including wild dog were prepared and summarized in Microsoft Office Excel 2003. The summaries were average pack size, minimum, and maximum pack size and age ratios. Similarly, the population size of carnivores other than the wild dogs was estimated in the excel sheet following Davis and Winstead (1980):

$P=A Z / 2 Y X$, where; $\mathrm{P}=$ population size $\mathrm{A}=$ Total study area

$\mathrm{Y}=$ Mean perpendicular sighting distance $\mathrm{X}=$ total length of all transects and

$\mathrm{Z}=$ Total number of animals counted

The density (D) of wild dogs was computed by dividing the population size $(\mathrm{N})$ by the size of the survey area $(\mathrm{A})$ (Wilson et al. 1996). The density of other carnivores was computed using the strip width transect for density estimate using line-transect (Buckland et al. 2001). On the other hand, data from random searches were collated in ArcGIS 9.2 (ESRI 2006) to map spatial distribution of the packs and habitat types for the wild dogs.

\section{Attitudes and threats of local people towards wild dogs}

The data generated through semi-structured interviews were translated from Kiswahili into English and categorized into themes and sub-themes, each of which was assigned an identification code for easy analysis. Descriptive analyses were employed in the Statistical Package for Social Sciences for Windows (SPSS 16). Relative importance of each threat was obtained by scoring and ranking technique (Kajembe and Kessy 2000). Other results were summarised in tables and graphs.

Later on, tissue samples were submitted to the Government Chief Chemist (GCC) in Dar es Salaam for toxicological analysis. Samples that were fixed in $10 \%$ buffered formalin were submitted for histopathological examination. The tissues were first processed routinely, embedded in paraffin, sectioned at $4 \mu \mathrm{m}$ and stained with hematoxylin-eosin ( $\mathrm{H}$ and $\mathrm{E})$. Few samples preserved in RNA later were used for the molecular analyses.

The messenger Ribonucleic Acid (mRNA) was isolated from two wild dog samples and Reverse transcriptasepolymerase chain reaction (RT-PCR) was performed.
Morbillivirus specific primers that amplify a region of the Pgene (P1: 5'-ATGTTTATGATCACAGCGGT-3' and P2: 5'-ATTGGGTTGCACCACTTGTC-3') (Barret et al. 1993) as well as primers homologous to sequences of the Fgene (FC1: 5' GGACTGATAATGTCCATTA-3' and FC2: 5'ATAGCTTTGTTAGACTGTT-3') were used (Liermann et al. 1998). The phylogenetic sequence on a $388 \mathrm{bp}$ fragment of a $\mathrm{P}$ gene was analyzed and the joining trees were generated using Tamura Nei parameter with 1000 bootstrap pseudo-replications (Kumar and Tamura 2004).

\section{RESULTS AND DISCUSSION}

\section{Population size and structures of wild dogs}

Over $75 \%(n=160)$ of the respondents from household interviews admitted having had seen wild dogs. Whereas, $24 \%(\mathrm{n}=50)$ respondents had not reported seeing wild dogs. The "yes" or "no" answer depended on how long a respondent had lived in the area by the time of survey, meaning that respondents who had shifted to the area in recent years had less chance of having sighted the animal compared to those who had lived in area for over five years.

Respondents reported having had sighted African wild dogs in groups of varying sizes (Table 2, Fig. 3). However, villagers in Piyaya and Malambo villages had an opportunity to see 4 of the 5 pack size categories whereas those in Soitsambu and Samunge saw the least number of pack size categories (Fig. 3). Overall, larger pack sizes, i.e. 21-30, 31-40 and those with individuals >40 were rarely seen compared to those with individuals between 1-10 and 11-20 with most pack sighted with 3 individuals (Table 2). Apparently, majority of respondents were unable to recognize sex of a wild dog as only 55 respondents (26\%) of all respondents were able to recognize only 2 adult males with the other 8 respondents (4\%) recognizing only 3 sub-adult females.

During the diurnal random searches for African wild dogs, a total of 8 packs were recorded in the area and given names depending on the pack's place of residence. The Tinaga pack was found to consist of 19 adult dogs whereas the Losoito pack in the central part of Loliondo had 15 subadult dogs. Also, 6 den sites were found with the number of pups ranging between 2 to 4 (Table 3) making a total of 132 individuals. The size of known packs ranged from 4 to 25 individuals with an average pack size of $16.50 \pm \mathrm{SD}$ 7.50 (CI, 0.50) animals. The pack sizes of known and unknown packs pooled together varied from 1-30 with average packs sizes of $9 \pm$ SD 5.70 (CI, 0.20).

Table 2. African wild dog pack sizes reported by respondents in six studied villages LGCA 2009

\begin{tabular}{lcccccc}
\hline Pack sizes & $\mathbf{1 - 1 0}$ & $\mathbf{1 1 - 2 0}$ & $\mathbf{2 1 - 3 0}$ & $\mathbf{3 1 - 4 0}$ & $\mathbf{> 4 0}$ & Total \\
\hline & & & & & & \\
Respondents (N) & 122 & 25 & 5 & 5 & 3 & 160 \\
Percentage (\%) & $76 \%$ & $16 \%$ & $3 \%$ & $3 \%$ & $2 \%$ & $100 \%$
\end{tabular}




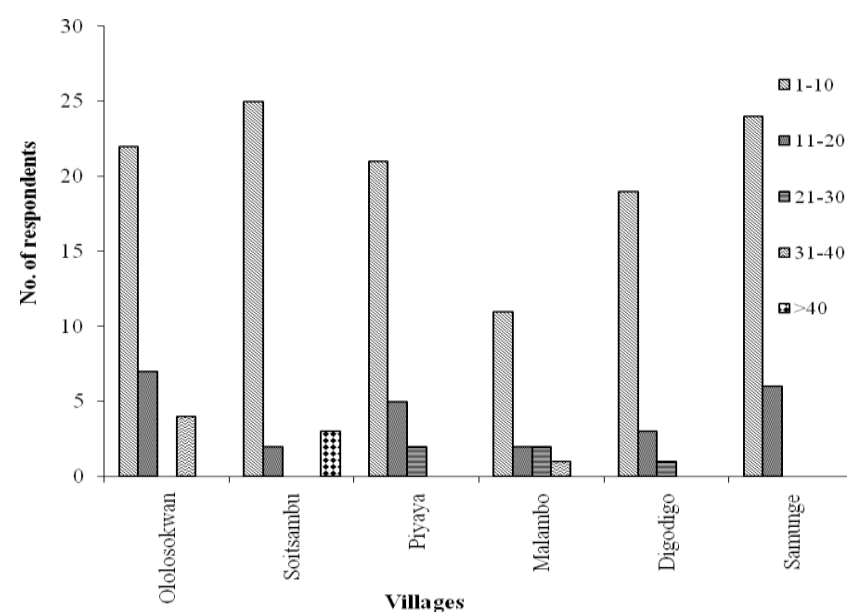

Figure 3. African wild dog pack sizes reported in six study villages in the LGCA 2009

Table 3. The sizes and age structures of known packs of wild dogs in the study area as identified during diurnal random searches in Loliondo Game Controlled Area 2009

\begin{tabular}{|c|c|c|c|c|}
\hline \multirow{2}{*}{ Pack name } & \multicolumn{2}{|c|}{ Age structures } & \multicolumn{2}{|c|}{ Pack size } \\
\hline & Adult & Sub adult & Pups & Total \\
\hline Losoito & 8 & 15 & 2 & 25 \\
\hline Malambo & 10 & 4 & 4 & 18 \\
\hline Masosu & 8 & 0 & 4 & 12 \\
\hline Ololosokwan & 7 & 7 & 4 & 18 \\
\hline Parimangati & 17 & 6 & 0 & 23 \\
\hline Samunge & 3 & 1 & 0 & 4 \\
\hline Tinaga & 19 & 0 & 4 & 23 \\
\hline Yasimdito & 6 & 0 & 3 & 9 \\
\hline Average & 9.75 & 4.13 & 2.63 & 16.50 \\
\hline Total & 78 & 33 & 21 & 132 \\
\hline
\end{tabular}

\section{Spatial distribution of African wild dog, population estimates and densities of other carnivores sighted during random searches}

Wild dogs were sighted inside and outside LGCA (Figure 4) and their pack sizes were recorded in various habitats/vegetation types (Figure 5). Sightings outside LGCA consisted of one sighting in the Maasai Mara, Kenya, and five sightings in Ngorongoro Conservation Area (NCA).

During the wild dog diurnal random searches, five categories of habitat were recorded (Fig. 6). The sightings were overlaid on the vegetation types to show the wild dogs sighted in different habitat types such as shrubland ( $\mathrm{n}$ $=2)$, woodland $(\mathrm{n}=46)$, grassland $(\mathrm{n}=17)$, bushland $(\mathrm{n}=$ 12) and anthropic landscape $(n=5)$ (Figure 7).

During the systematic night transect survey, neither lion nor wild dogs were recorded. Other small and large carnivores were counted and their population estimates are presented in Table 4. The densities of all carnivores recorded were calculated (Table 5) without carnivores with observation less than 5. However, the density for wild dogs itself was 0.19 animals $/ \mathrm{km}^{2}$ for the whole surveyed area.

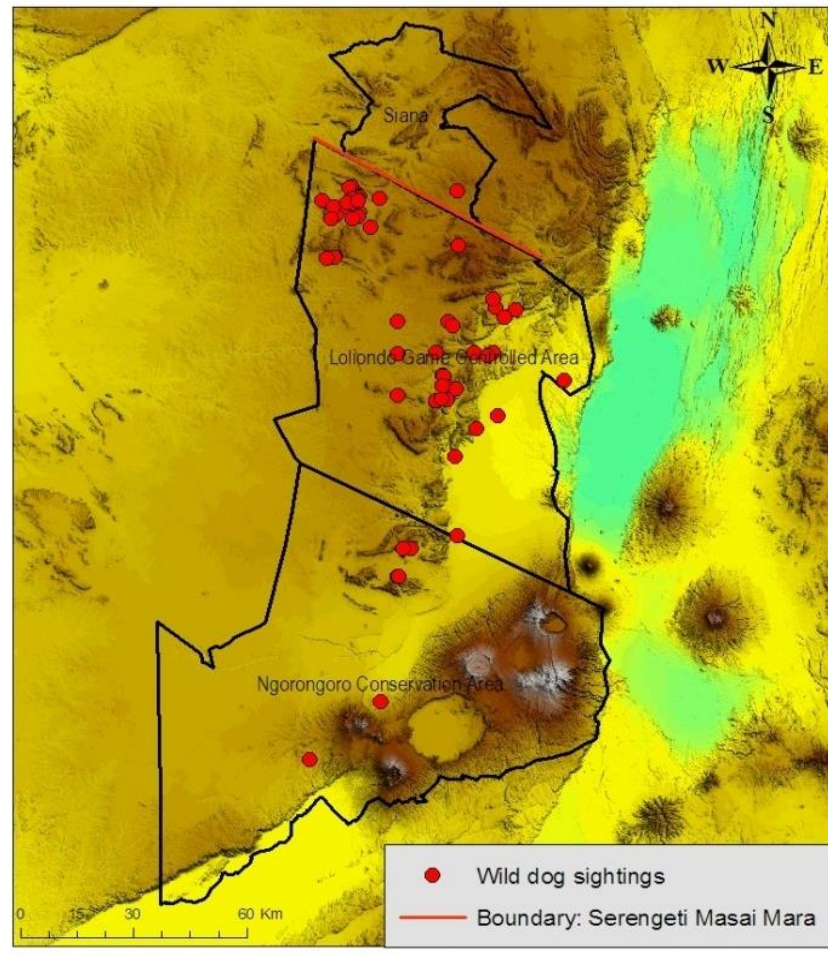

Map datum and Projection: Arc 1960, Zone 36S; Data source: Wild dog Projed 2009; Map drawn by Masenga

Figure 4. Spatial distribution of wild dogs in LGCA and the adjacent environs based on sightings during the diurnal random searches (Map background SRTM)

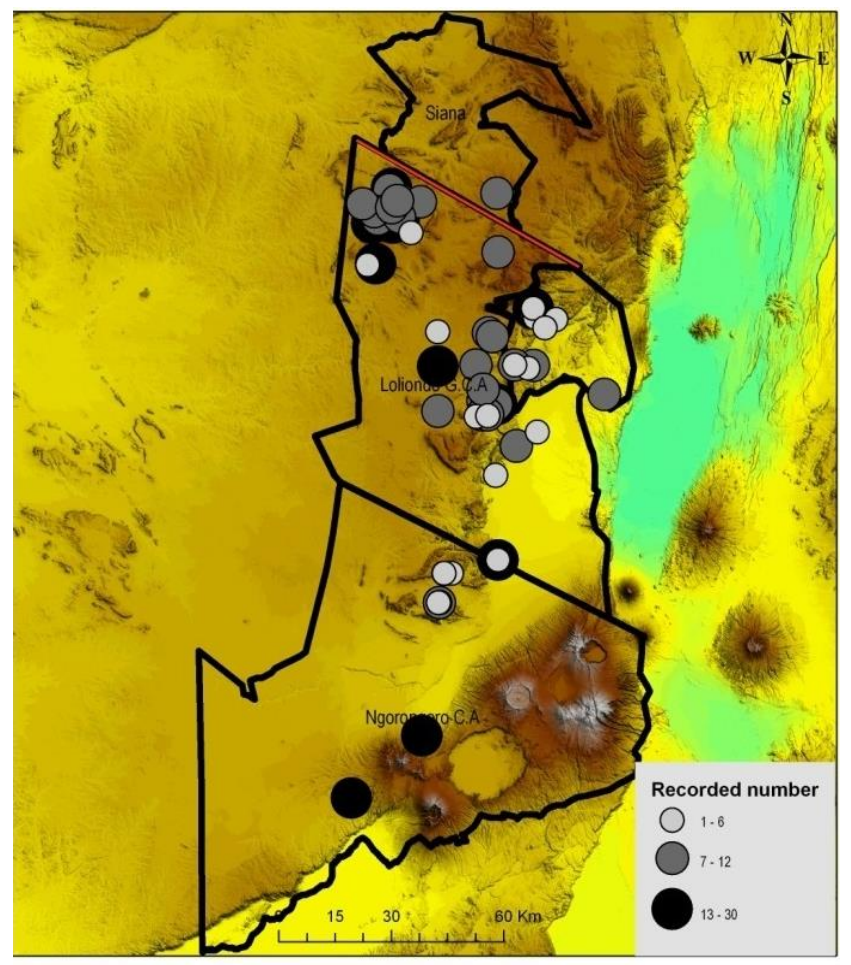

Map datum and Projection: Arc 1960, Zone 36 S; Map drawn by Masenga

Figure 5. Different pack sizes as sighted in various localities within and outside LGCA during the diurnal random searches in 2009 (Map background SRTM) 


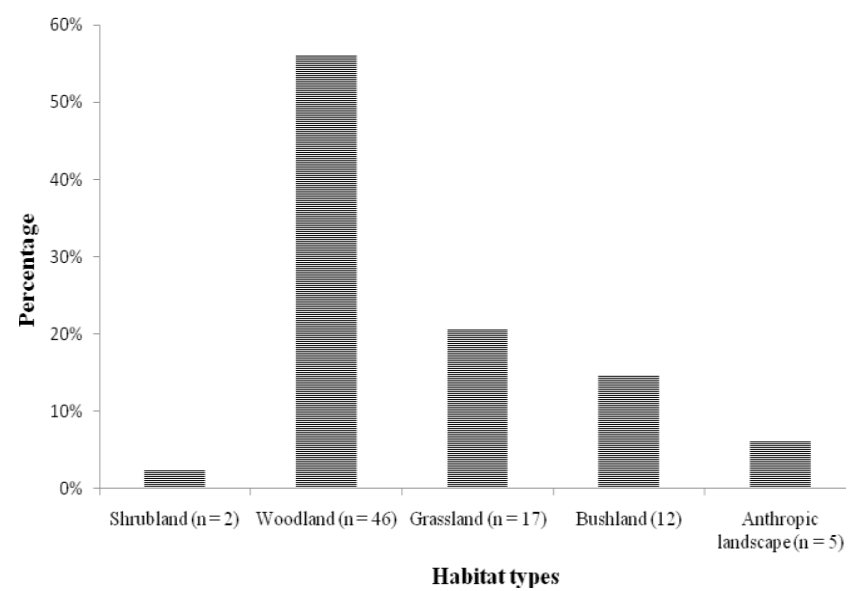

Figure 6. Relative occurrences of the African wild dogs in various habitats in LGCA 2009

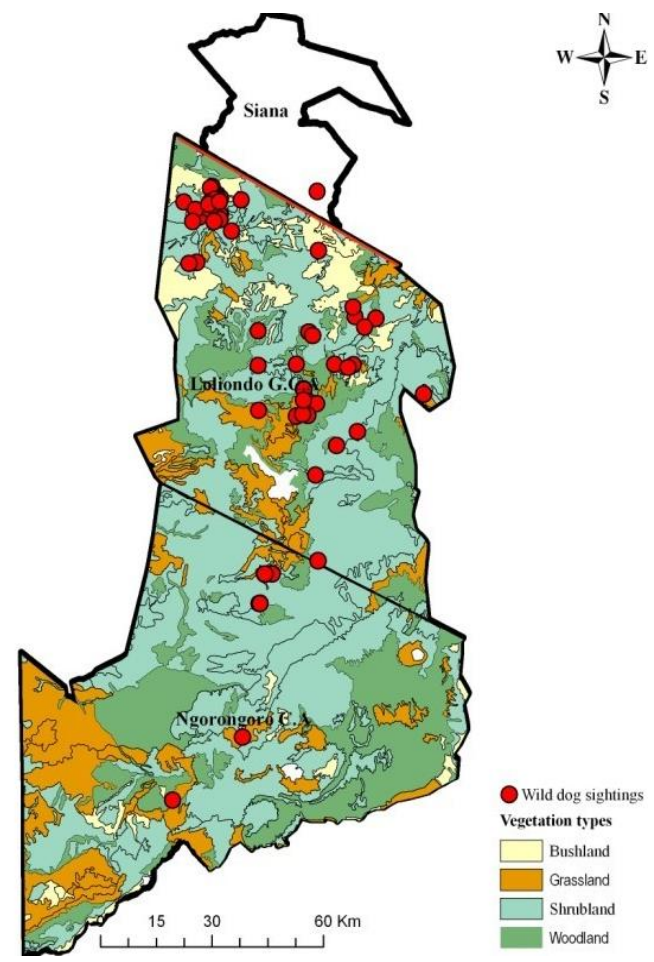

Figure 7. Wild dogs sighting in various vegetation types in LGCA and its adjacent areas (Map background SRTM)

\section{Attitudes of local people towards wild dogs and wild dog conservation}

Respondents had varied opinions regarding presence of wild dogs within their area. Over one-third (40\%) showed a negative attitude towards the wild dog for reasons such as fear of livestock predation and human attack. The positive attitude towards the animal (55.3\%) such as very happy about wild dogs and the animal is good for tourist attraction but difficult to see (Table 6). Such positive statements were based on the understanding that the animal was rare and therefore important for income generation and employment in tourism industry.
Table 4. Small and large carnivores other than wild dog and lion that were counted in LGCA during the estimate of each species night surveys and the corresponding

\begin{tabular}{|c|c|c|}
\hline $\begin{array}{l}\text { Month/ } \\
\text { species }\end{array}$ & Counts & Estimates \\
\hline \multicolumn{3}{|l|}{ January 2009} \\
\hline Black-backed jackal & 1 & 4800 \\
\hline White-Tailed Mongoose & 7 & 5600 \\
\hline Domestic cat & 1 & 4800 \\
\hline \multicolumn{3}{|l|}{ February 2009} \\
\hline Black-backed jackal & 4 & 6400 \\
\hline Golden Jackal & 3 & 4000 \\
\hline Spotted hyaena & 2 & 9600 \\
\hline Bat Eared Fox & 2 & 1600 \\
\hline \multicolumn{3}{|l|}{ March 2009} \\
\hline Golden Jackal & 3 & 27600 \\
\hline Spotted hyaena & 2 & 9600 \\
\hline White-Tailed Mongoose & 7 & 13070 \\
\hline Bat Eared Fox & 27 & 35100 \\
\hline Black-backed jackal & 1 & 1600 \\
\hline \multicolumn{3}{|l|}{ April 2009} \\
\hline Bat Eared Fox & 10 & 18000 \\
\hline Serval cat & 2 & 800 \\
\hline \multicolumn{3}{|l|}{ May 2009} \\
\hline Bat Eared Fox & 7 & 44800 \\
\hline Aardvark & 1 & 3200 \\
\hline Striped hyaena & 1 & 3200 \\
\hline Wild cat & 1 & 800 \\
\hline \multicolumn{3}{|l|}{ August 2009} \\
\hline Golden Jackal & 3 & 20800 \\
\hline Bat Eared Fox & 6 & 28800 \\
\hline African civet & 1 & 4800 \\
\hline \multicolumn{3}{|l|}{ September 2009} \\
\hline Golden Jackal & 3 & 21600 \\
\hline Bat Eared Fox & 2 & 11200 \\
\hline \multicolumn{3}{|l|}{ October 2009} \\
\hline Wild cat & 1 & 6400 \\
\hline Golden Jackal & 1 & 6400 \\
\hline Bat Eared Fox & 3 & 19200 \\
\hline \multicolumn{3}{|l|}{ November 2009} \\
\hline White-Tailed Mongoose & 2 & 12800 \\
\hline Domestic dog & 1 & 1600 \\
\hline Wild cat & 1 & 4800 \\
\hline Golden Jackal & 1 & 3200 \\
\hline Bat Eared Fox & 1 & 3400 \\
\hline
\end{tabular}

Table 5. Summary of frequency of carnivore sightings and densities from January-November 2009

\begin{tabular}{lcc}
\hline Species & Counts & $\begin{array}{c}\text { Density } \\
\text { (animals/km } \mathbf{~} \text { ) }\end{array}$ \\
\hline Bat-eared fox & 58 & 0.07 \\
Black-backed jackal & 6 & 0.01 \\
Golden jackal & 14 & 0.02 \\
White-tailed mongoose & 16 & 0.02 \\
\hline
\end{tabular}

Table 6. Local communities' attitude towards wild dogs occurring on their land in the LGCA 2009

\begin{tabular}{lcc}
\hline Respondents feeling & $\begin{array}{c}\text { Number of } \\
\text { respondents }\end{array}$ & Percentage \\
\hline Dangerous to livestock & 77 & 36.70 \\
Very happy & 68 & 32.40 \\
A good for tourist attraction & 39 & 18.60 \\
Good but they are difficult to see & 9 & 4.30 \\
Fear them & 7 & 3.30 \\
Feel normal (Not afraid of the dogs) & 10 & 4.80 \\
Total & 210 & 100.00 \\
\hline
\end{tabular}


Table 7. Local communities initiatives towards wild dog conservation in the LGCA 2009

\begin{tabular}{|c|c|c|}
\hline Initiatives & $\begin{array}{l}\text { Number of } \\
\text { respondents }\end{array}$ & Percentage \\
\hline Rising conservation education & 76 & 36.10 \\
\hline Encourage villagers to do wild dog watching & 13 & 6.20 \\
\hline $\begin{array}{l}\text { Village should formulate by-laws to } \\
\text { safeguard the animal }\end{array}$ & 10 & 4.80 \\
\hline No effort made to conserve wild dogs & 111 & 52.90 \\
\hline Total & 210 & 100.00 \\
\hline
\end{tabular}

Table 8. Summary of responses to the question regarding threats to wild dogs in LGCA 2009

\begin{tabular}{lcc}
\hline Type of threat & \multicolumn{2}{c}{$\begin{array}{c}\text { Number of } \\
\text { respondents }\end{array}$} \\
\hline Don't know & 74 & 35.20 \\
Moved away from the area & 35 & 16.70 \\
Climate change & 33 & 15.70 \\
Livestock and human population increase & 22 & 10.50 \\
Persecution & 17 & 8.10 \\
Decline of preferred prey & 16 & 7.60 \\
Diseases e.g. Rabies & 9 & 4.30 \\
Less pups borne & 4 & 1.90 \\
Total & 210 & 100 \\
\hline
\end{tabular}

Nevertheless, majority of community members (52.9\%) were disappointed by the fact that no conservation initiatives were in place to conserve this rare and endangered animal. In contrast, less than $10 \%$ $(6.2 \%+4.8 \%)$ of respondents reported presence of a minimum level in place of initiatives for the conservation of this rare animal as implied by statements such as "advocate wild dog watching and formulation of by-laws" (Table 7).

\section{Threats to wild dog conservation \\ Ultimate and proximate threats}

During the interview, a total of 210 respondents responded to the question regarding threats to survival of the African wild dog. The responses were rendered into 9 groups of threats. But, majority of respondents appeared to have no idea about the probable cause for wild dog decline (Table 8).

\section{Poisoning}

The results from the local laboratory (GCC) detected presence of organ phosphorus pesticides in liver, kidneys, and spleen in 4 of 23 wild dog carcasses that were suspected of poisoning. However, lungs, intestines, and stomach had no trace of organophosphorus pesticides.

\section{Diseases}

The histopathological examination of liver, spleen, lung, heart, kidney, and brain revealed moderate to severe multi-lobular suppurative to necrotizing bronchopneumonia. In addition, there was extensive intraalveolar and interstitial infiltration with mononuclear inflammatory cells. Epithelial lining cells of bronchi and bronchioli contained clearly visible eosinophilic intracytoplasmic inclusion bodies. There was also multifocal moderate to severe interstitial pneumonia in some animals with formation of multiple syncytial cells. Occasionally, marked interstitial edema with some intraalveolar hemorrhages and fibrin deposits were observed.

Some neutrophilic granulocytes were observed indicating secondary bacterial infection. These findings are consistent with canine distemper virus (CDV) infection.

The RT-PCR amplification and Sequencing together with phylogenetic analysis of amplified P-gene fragment of size 388bp obtained from the liver, spleen, lung, heart, kidney, and brain demonstrated a CDV strain closely related to CDV strains previously described for lions, spotted hyenas and bat-eared foxes in Serengeti National Park, and those described for domestic dogs outside the park and wild dogs held in captive breeding program in Mkomazi Game Reserve. Some neutrophilic granulocytes were also observed indicating secondary bacterial infection.

\section{Discussion \\ Population size and structures of wild dogs}

African wild $\operatorname{dog}$ is among large carnivores now endangered second to Ethiopian Wolf (Woodroffe et al. 2005). Therefore, their occurrence in any area draws attention to their conservation. LGCA which has a remnant population is among the remaining core areas in the Serengeti ecosystem. The sightings have been known to the local communities living in the area as resident individuals. The wild dog packs sizes of 1 to 10 individuals were reported in all studied villages whereas packs with $>40$ individuals were reported in only one village. However, respondents have no idea about the number of packs seen in the area due to inability to recognize individuals of various packs. Pack sizes were defined as the number of adults of $\geq 1$ year of age (McNutt and Silk 2008). Results of this study, therefore, correspond to previous reports in the same ecosystem (Burrows 1995) that wild dogs are still seen in small pack sizes.

Formerly, the SNP supported several wild dog packs though the densities had never been high (Creel and Creel 2002; Woodroffe et al. 2004; IUCN/SSC 2008). This study reports 8 packs, comprised of 132 individuals. This population size is lower compared to previous estimates for known packs in Tanzania, except for the wild dog pack in the Maasai Steppe, which was reported to have only 8 packs ( $\mathrm{n}=70$ individuals) (TAWIRI 2009). According to Creel and Creel (2002) and IUCN/SSC (2008), Katavi had 17 packs making 200 individuals; Kigosi-Moyowosi 33 packs making 400 individuals; Rungwa-Ruaha 35 packs making 500 individuals and Selous 50 packs constituting 880 individuals. The present study on both known and unknown packs in LGCA range from 1 to 30 with average pack size of $9.10 \pm$ SD $5.70(n=82)$ which does not concur with the other findings. In Luangwa protected area complex $\left(48,180 \mathrm{~km}^{2}\right)$ in Zambia probably holds the second largest wild dog population in Africa with mean 
pack size of $8.80 \pm$ SD $5.10(n=24)$ with a pack size ranging from 1 to 27 (Somers et al. 2008). Similarly, wild dog pack sizes in Northern Botswana varied from 2 to 30 adults, with an average pack size of $10.40 \pm$ SD 5.40 ( $\mathrm{n}=$ 84) (McNutt and Silk 2008). The lower mean pack size in this study was contributed by communities disturbing the dogs so the dogs dispersed widely.

The current recorded population size of wild dogs is larger compared to what has been reported previously by Masenga and Mentzel (2005). The observed increase is linked to relatively lower carnivore populations as reported in this study. However, during the study period, there was no wild dog recolonization inside Serengeti Park. This is probably due to increased hyena and lion numbers in the Serengeti National Park causing high interspecific competition (Woodrofe et al. 2004).

\section{Spatial distribution of African wild dog, population estimates and density of carnivores other than African wild dog}

Wild dogs in LGCA were found concentrated in the northern part. But they were sparsely distributed in the central part and scattered in the southern part. The order and magnitude of sightings of wild dog packs in different vegetation types of LGCA with most sightings in the woodlands (Fig. 6) are comparable to findings in Selous Game Reserve whereby wild dogs were also found to prefer woodland and bushland due to good cover (Creel and Creel 2004). However, sightings of the same wild dog packs in LGCA and NCAA, Tanzania, and Maasai Mara, Kenya suggest that wild dogs in Loliondo can also use other areas of the Serengeti Ecosystem.

Habitat variation in LGCA (i.e. woodland, shrubland, bushland, and anthropic landscapes) in combination with hills and rock outcrops possibly contributes to the tendency of wild dogs to concentrate more in the area. In other studies showed that in Ethiopian Montane forest and East African mangrove in Ijara-Lamu in Kenya are one of ecological habitat uniqueness of wild dogs confirmed to occur (Dutson and Sillero-Zubiri 2005; IUCN/SSC 2008). Other factors could be the influence of wildebeest migration that occurs between December and May every year on the Southern part of Serengeti ecosystem (Holdo et al. 2010). The migrating animals could be a good source of food supply to the wild dogs in the area. Contrary, studies in Hwange National Park, north-western Zimbabwe reported wild dogs to occur most in deciduous tree savanna, which constituted about $45 \%$ of the entire range (Rasmussen et al. 2008).

The results from the systematic night transect survey revealed few counts for all carnivores with a special case of no wild dogs and lion sightings. The probable cause for not sighting wild dogs could be the activity pattern of the species, being more active during the day than at night. However, absence of lions during the counts may be associated with Maasai culture to kill lions as part of "Moran" prestige or moved to other areas. In Simanjiro lion has been killed by humans and they moved away from adjacent boundary to Tarangire national park (Kissui 2008).
The low numbers for other carnivores despite being lower than that of wild dogs could be due to high densities of livestock and human increased demand for cultivation (Ojalammi 2006) as well as drought during the survey period. In this study, the presence of low numbers of both large and small carnivores during the night surveys suggested that competition during wild dogs hunting would be low thus reducing inter-specific competition. Results of the study in Laikipia-Kenya showed that low densities of small carnivores allow for increase in wild dog population as they avoid inter-specific competition with lions (Woodroofe et al. 2005) by avoiding lion and hyenas home ranges. These findings are in line with the present study. Nevertheless, other findings reported that wild dog can coexist with people only under right circumstances such as high density of prey ungulates (Treves et al. 2004), low densities of domestic dogs, and human (Woodroofe et al. 2004; Creel and Creel 2004).

The overall wild dog density (known and unknown packs) in this study area was 0.19 animals/sq $\mathrm{km}$. By comparison, the density of adult wild dogs was 0.0195 adults/sq $\mathrm{km}$ which is relatively lower than what has been recorded in Selous Game Reserve, 0.04 animals/sq km (Creel and Creel 2002) and 1.6 adults/sq km in HluhluweiMfolozi Park (Somers et al. 2008). However, the adult population density on the Serengeti plains over 13 years averaged 0.01 animals/sq km (Burrows 1995) which is lower than what has been recorded in this study.

\section{Attitudes of local people towards wild dogs and wild dog conservations}

The results from respondents revealed that majority had negative attitude on wild dog presence on their land. This was due to wild dog attacks on their livestock. However, livestock depredations by wild dogs were said to peak during dry season. During this time of the year when migratory herbivore species particularly wildebeests are away, livestock is concentrated in habitat patches with few types of grass remaining. Consequently, livestock serves as cheap and easily available prey. Presence of wildebeest migration in the area during wet season implies high abundance of prey thus wild dogs switch their feeding preference from livestock to wildebeest and other wild prey, which reduces the wild dog-human conflict. However, the retaliatory actions by local communities versus wild dogs persist following the negative attitude already developed (Marker et al. 2003). The negative attitude by livestock keepers and ranchers towards wild dogs is due to economic loss they cause (Woodroffe et al. 2005; Lindsey et al. 2005).

The local communities realize that wild dogs are rare and important for the tourism industry. The family members who were engaged directly in taking tourists to watch wild dogs gained incentives for wild dog viewing from tourists. In addition, tour operators offer employment to members of local communities with experience in areas where wild dogs use mostly. The benefit-sharing through wild $\operatorname{dog}$ as an asset between local communities and tourists/tour operators, have been observed in the Ololosokwan, Soitsambu and Piyaya villages. Based on 
these kinds of values, local communities who are beneficiaries may develop a positive attitude toward wild dogs and wild dog conservation. Therefore, understanding local community attitudes towards carnivores including wild dog may contribute to better management and identification of carnivores ecology, behavior, and conservation status through integrating local communities in management (Dickman 2005).

Increased education and outreach activities regarding wild dog conservation would also be beneficial to conservation. The observed positive contact between local communities and tour operators was indicative of improved attitudes towards the wild dog, demonstrating that such contact can have clear benefits. Although some conservation education programs have been established for schoolchildren to visit the Serengeti National Parks, this has little relevance to nomadic pastoralists. Still, it would be valuable to develop similar schemes with pastoralists, and to use these programs to highlight the presence of wild dogs in their area, with the aim of improving attitudes not only towards the wild dog, but also towards other wildlife species.

Although wild dog is an endangered species, this study showed that majority of respondents felt that there were not yet any conservation initiatives in place to serve the species. This was due to lack of Government conservation guidelines for the species in Tanzania. The community opinion on the inspire community to kill the dogs, awareness-raising and provision of community conservation education are of importance to serve the species. The action plan for wild dog conservation has identified priority areas for species conservation but rather has not emphasized on formulation of by-laws to safeguard the species conservation (TAWIRI 2009). In Kruger National Park, tourist volume is high and almost $75 \%$ of guests are willing to pay to see wild dogs. These revenues are potentially sufficient for conservation initiatives in the country (Lindsey et al. 2005). However, in LGCA wild dog watching campaign and formulation of by-laws were not in place as suggested by respondents. Therefore, in order to ensure sustainable conservation initiatives for the species in LGCA, raising conservation awareness needs to be emphasized.

\section{Threats to African wild dog populations}

It is, however, important to understand immediate and ultimate threats to wild dogs. Results suggest that immediate wild dog threats were not known to a greater proportion of local community, therefore aspect such as dog emigration and weather change was viewed by respondents as the ultimate threats. Their notions about the threats were based on their knowledge of the ecology of the species, which include their wide-ranging behavior. It is documented that wild dogs require large home ranges to support viable populations (Creel and Creel 2002; Woodroffe et al. 2004).

The respondents mentioned human and livestock population increase, persecution, decline of preferred prey, diseases, and fewer pups borne as threats to wild dogs. However, habitat fragmentation has caused decline of wild dog home ranges to extend beyond reserve borders, leading to increased mortality risk due to persecution by humans, and poaching activity such as snares which can cause considerable death to dogs (IUCN/SSC 2008). Woodroffe et al. (2005) also pointed out that indiscriminate killing of wild dogs by game rangers may be led to its population decline. With high proportion of dogs killed by people, human induced mortality has been identified as threat to wild dogs as it appears to increase due to decline in monitoring intensity (Woodroffe et al. 2004).

One pack in the study area continues to decline as a result of ongoing conflict with humans. The conflict between wild dogs and human has led to intentional poisoning of the dogs due to wild dog attacks on their livestock. This has resulted in death of $65 \%$ of Parimangati packs due to poisoning in Ololosokwan village. The poison used contained organophosphate compounds that are found in cattle dip for killing ticks on livestock. The magnitude of mortality identified in this study was similar to that reported by Woodroffe et al. (2004) for other wild dog populations elsewhere in Africa, for which poisoning itself contributed about $8 \%$ of the population. Poisoning of wild dogs in LGCA is done in secrecy because for the Maasai it is an abomination to kill wild dogs. Therefore, most poisoning incidences were not reported (IUCN/SSC 2008).

The wild dog appears to be susceptible to many diseases; particularly canine distemper virus that has been confirmed to kill considerable population of the Parimangati pack. In Mkomazi Game Reserve, Tanzania, Canine Distemper outbreak caused death to a captive-bred population, 49 out of 52 individual dogs died between December 2000-February 2001 (Marco et al. 2002).

The histopathological lesions described in the result section were consistent with the gross pathological examination suggesting that the pathological changes were due to viral and secondary bacterial infection. Detection of genetic material for CDV by RT-PCR can be a result of circulating antigens from previous exposure to CDV (Goller et al. 2010). However, it is unlikely for the noninfectious antigens to cause pathological lesions with intracytoplasmic inclusion bodies which are pathognomonic for clinical CDV infection. The secondary bacterial infection probably exacerbated the severity of CDV infection. The detected CDV strain in the recent infection is similar to previously described strain in wild carnivores suggesting that the virus is still circulating in an unknown reservoir within the Serengeti ecosystem.

\section{Conclusion}

From this study, it is not easy to draw up conclusion of the small pack sizes recorded during the diurnal random searches and reported by the respondents. However, some more in-depth information (pack recruitment and, birth and death rate within and among pack members) are required to explain the presence of the low population sizes. The information provided shows that the wild dogs in the LGCA are magnificent carnivores among others as they had not been sighted in the Serengeti National Park which has potential for tourists during the study period. 
The findings indicate that the spatial distribution of wild dogs formed access for wild dog game viewing in the area by tourists. Although, the nature of the wild dogs to prefer more woodland habitat types may obscure the visibility of the animal when searched by the people. Also, the nature of protected areas (game reserves) allowing the co-existence of mankind and wildlife in the natural settings poses a challenge wild dogs sighting. Thus most of these sightings were not close to human settlement (i.e. in areas close to human settlement such Sonjo area less sightings were reported compared to Maasai area with a vast land unoccupied by humans). In addition, the night transect surveys showed the presence of more sightings of small carnivores compared to large carnivores, suggesting that large carnivores were persecuted and as the result, they avoid human areas.

In terms of attitudes of communities towards wild dog conservation much need to be done to improve coexistence between human and wild dogs. Most likely the tendency of local communities to dislike the presence of this endangered species on their land is not promising for the species future survival. Since, there is no effort in place to conserve the species by the communities there is no hope for the sustainable utilization of the species in order to improve the community livelihood.

Most of the threats faced by wild dogs in this study are hazardous to the future survival of the species. The combination of poisoning and diseases is a great challenge to conserve the species in the area. This is contributed by the nature of the species behavior as they range widely and make it easier to continue contact with human activities which may lead to conflict with the wild dogs as the result of persecution may increase. In terms of diseases, wild dogs range widely and they are exposed more to disease transmissions such as CDV and rabies when affecting the pack.

\section{REFERENCES}

Alexander KA, Appel JG. 1994. African wild dog (Lycaon pictus) endangered by Canine Distemper epizootic among domestic dogs near the Maasai Mara National Park, Kenya. Journal of Wildlife Diseases 30 (4): 481-485. DOI: 10.7589/0090-3558-30.4.481

Barret T, Visser IKG, Mamaev L, Goatley L, Van Bressem MF, Osterhaus AD. 1993. Dolphin and porpoise Morbilliviruses are genetically distinct from Phocine Distemper Virus. Virology 193: 1010-1012. DOI: 10.1006/viro.1993.1217

Buckland ST, Anderson DR, Burnham KP, Laake JL, Borchers DL, Thomas L. 2001. Introduction to Distance Sampling Estimating Abundance of Biological Populations. Oxford University Press, New York.

Burrows R. 1995. Demographic changes and social consequences in Wild Dogs, 1964-1992. In: Sinclair ARE, Arcese P (eds.). Serengeti II: Dynamics, Management and Conservation of an Ecosystem. University of Chicago Press, Chicago.

Creel S, Creel NM. 2002. The African Wild Dog: Behaviour, Ecology, and Conservation. Princeton University Press, Princeton.

Creel S, Creel NM. 1996. Limitation of African wild dogs by competition with hunting dogs. Nature 205: 442-444.

Creel S, Michael L, Mills J, McNutt W. 2004. Demography and Population Dynamics of African Wild Dogs in Three Critical Populations. In: Macdonald DW, Illero-Zubiri C (eds.). Biological Conservation of Wild Canids. Oxford University Press, UK. der Gier A. 2004. Sampling Concepts and how to handle them. Enschede: Lecture Handout, International Institute for Geo Information Science and Earth Science and Earth Observation, Germany.

Dickman AJ. 2005. An assessment of pastoralist attitudes and wildlife conflict in the Rungwa-Ruaha Region, Tanzania, with particular reference to large carnivores. [Thesis]. University of Oxford, United Kingdom.

Dutson G, Sillero-Zubiri C. 2005. Forest-dwelling African wild dogs in the Bale Mountains, Ethiopia. Canid News 8: 1-6.

Goller KV, Fyumagwa RD, Nikolin V, East LM, Kilewo M, Speck S, Muller T, Matzke M, Wibbelt G. 2010. Fatal canine distemper infection in a pack of African wild dogs in the Serengeti ecosystem, Tanzania. Vet Microbiol 17: 310-318. DOI: DOI: 10.1016/j.vetmic.2010.05.018

Holdo RM, Holt RD, Galvin K, Polasky S, Knapp E, Hilborn R. 2010. Responses to alternative rainfall regimes and antipoaching enforcement in a migratory system. Ecological Applications 20: 381397. DOI: $10.1890 / 08-0780.1$

Homewood K, Lambin ET, Coast E, Kariuki A, Kikula I, Kivelia J, Said M, Serneels S, Thompson M. 2001. Long-term changes in SerengetiMara wildebeest and land cover: pastoralism, population, or policies? Ecology 98 (22): 12544-12549. DOI: 10.1073/pnas.221053998

IUCN/SSC. 2008. Regional Conservation Strategy for the Cheetah and African Wild Dog in Eastern Africa. IUCN Species Survival Commission, Gland, Switzerland.

Kajembe GC, Kessy JF. 2000. Joint Forest Management in Urumwa Forest Reserve, Tabora, Tanzania: A process in the making. Silva Carelica 34: 141-158.

Kissui BM. 2008. Livestock predation by lions, leopards, sported hyenas, and their vulnerability to retaliatory killing in the Maasai steppe, Tanzania. Animal Conserv 11: 422-432. DOI: 10.1111/j.14691795.2008.00199.x

Kumar S, Tamura K. 2004. Integrated software for molecular evolutionary genetics analysis and sequence alignment. Brief Bioinform 5: 150163. DOI: $10.1093 / \mathrm{bib} / 5.2 .150$

Liermann H, Harder TC, Lochelt M, Von Messling V, Baumgartner W, Moennig V. 1998. Genetic analysis of the central untranslated genome region and the proximal coding part of the $\mathrm{F}$ gene of wild type and vaccine distemper morbilliviruses. Virus Genes 17: 259-270. DOI: $10.1023 / \mathrm{a}: 1008069805011$

Lindsey PA, Alexander RR, du Toit JT, Mills MGL. 2005. The potential contribution of ecotourism to African wild dog (Lycaon pictus) conservation in South Africa. Biol Conserv 123: 339-348. DOI: 10.1016/j.biocon.2004.12.002

Lindsey PA, Alexander R, Mills MGL, Romañach SS, Woodroffe R. 2007. Wildlife viewing preferences of visitors to protected areas in South Africa: Implications for the role of ecotourism in conservation. J Ecotour 6: 19-33. DOI: 10.2167/joe133.0

Marco WG, van de Bildt, Thijs K, Visee M, Lema S, Fitzjohn RT, Albert DME. 2002. Distemper outbreak and its effect on African wild dog conservation. Emerg Infect Dis 8 (2): 211-213. DOI: 10.3201/eid0802.010314

Marker LL, Dickman AJ, Mills MGL, Macdonald DW. 2003. Aspects of the management of cheetahs (Acinonyx jubatus) trapped on Namibian farmlands. Biological Conservation 114: 401-412. DOI: 10.1016/S0006-3207(03)00068-5

Masenga HE, Mentzel C. 2005. Preliminary results from a newly established population of African wild dogs (Lycaon pictus) in the Serengeti-Ngorongoro ecosystem, northern Tanzania. In: Proceedings of the $5^{\text {th }}$ Annual Conference of the Tanzanian Wildlife Research Institute, Arusha, Tanzania, 1-3 December 2005.

McNutt JW, Silk JB. 2008. Pup production, sex ratios, and survivorship in African wild dogs (Lycaon pictus). Behav Ecol Sociobiol 62: 10611067. DOI: 10.1007/s00265-007-0533-9

McNutt JW, Parker MN, Swarner MJ, Gusset M. 2008. Adoption as a conservation tool for endangered African wild dogs (Lycaon pictus). S A J Wildlife Res 38 (2): 109-112. DOI: 10.3957/0379-436938.2.109

Mills MGL, Gorman ML. 1997. Factors affecting the density and distribution of African wild dogs in Bale Mountains, Ethiopia. Canid News 8: 1-6.

NDC. 2009. Ngorongoro District Council Annual Report. Ngorongoro, Arusha, Tanzania.

Norton-Griffiths M, Herlocker DJ, Pennycuick L. 1975. The patterns of rainfall in the Serengeti ecosystem, Tanzania. East Africa Wildlife J 13: 347-375. DOI: 10.1111/j.1365-2028.1975.tb00144.x 
Ojalammi S. 2006. Contested Lands: Land Disputes in Semi-arid Parts of Northern Tanzania. Case Studies of the Loliondo and Sale Divisions in the Ngorongoro District. Dissertation for Award MSc. Degree at University of University of Helsinki, Siltavuorenpenger, Finland.

Oliver M, Lambin X, Cornulier T, Piertney S. 2009. Spatio-temporal variation in the strength and mode of selection acting on major histocompatibility complex diversity in water vole (Arvicola terrestris) metapopulations. Mol Ecol 18: 80-92. DOI: 10.1111/j.1365-294X.2008.04015.x

Rasmussen GSA, Gusset M, Courchamp MF, Macdonald DW. 2008 Achilles' Heel of sociality revealed by energetic poverty trap in cursorial hunters. Amer Nat 172: 508-518. DOI: 10.1086/590965

Sancheti DC, Kapoor VK. 2007. Statistics Theory, Methods and Application. Published by Sultan and Sons, Daryaganj, New Delhi.

Sinclair ARE, Mduma SAR, Arcese P. 2002. Protected areas as biodiversity benchmarks for human impact: Agriculture and the Serengeti avifauna. Biol Sci 269 (1508): 2401-2405. DOI: 10.1098/rspb.2002.2116

Somers MJ, Graf JA, Rob SM, Gusset SM. 2008. Dynamics of a small reintroduced population of wild dogs over 25 years: Allee effects and the implications of sociality for endangered species' recovery. Oecologia 158: 239-247. DOI: 10.1007/s00442-008-1134-7

TAWIRI. 2009. Tanzania Carnivore Conservation Action Plan. Tanzania Wildlife Research Institute, Arusha, Tanzania.

Treves A, Naughton-Treves L, Harper EK, Mladeno DJ, Rose RA, Sickley TA, Wydeven AP. 2004. Predicting human-carnivore conflict: A spatial model derived from 25 years of data on wolf predation on livestock. Conserv Biol 18: 114-125. DOI: 10.1111/j.1523-1739.2004.00189.x

UNEP. 2008. Serengeti National Park. [http://www.unepwcmc.org/sites.html] site visited on 23/05/2010. van de Bildt MWG, Kuiken T, Visee AM, Lema S, Fitzjohn TR, Osterhaus DME. 2002. Distemper outbreak and its effect on African wild dog conservation. Emerg Infect Dis 8 (2): 211-213. DOI: 10.3201/eid0802.010314

Woodroffe R. 1998. The African wild dog-conservation planning for Southern Africa. Oryx 32: 13-14.

Woodroffe R. 1997. The conservation implications of immobilizing, radio-collaring and vaccinating free-ranging wild dogs. In: Woodroffe R. et al. (eds.), The African Wild Dog: Status Survey and Conservation Action Plan. IUCN, Gland.

Woodroffe R, Ginsberg JR. 1998. Edge effects and the extinction of populations inside protected areas. Science 280: 2126-2128. DOI: $10.1126 /$ science. 280.5372 .2126

Woodroffe R, Ginsberg JR, MacDonald DW. 1997. The African Wild Dog: Status Survey and Action Plan. IUCN (World Conservation Union)/CSG (Canid Specialist Group). Gland, Switzerland and Cambridge, United Kingdom.

Woodroffe R, André J, Andulege B, Bercovitch F, Carlson A, Coppolillo P, Davies-Mostert H, Dickman A, Fletcher P, Ginsberg J, Hofmeyr M, Laurenson K, Leigh K, Peter L, Lines L, Mazet J, McCreery K, McNutt J, Mills G, Msuha M, Munson L, Parker M, Pole A, Rasmussen G, Robbins R, Sillero-Zubiri C, Swarner M, Szykman M. 2004. Tools for the Conservation of African Wild Dogs. Do we know enough? What more do we need to know? Proceeding of Research for Conservation of the African wild dog Workshop, Kruger National Park, South Africa, 25-29 October 2004.

Woodroffe R, Lindsey PA, Romañach SS, Stein A, Ranah SMK. 2005. Livestock predation by endangered African wild dogs (Lycaon pictus) in Northern Kenya. Biol Conserv 124: 225-234. DOI: 10.1016/j.biocon.2005.01.028 